\title{
Phraseology in Learner Language: The Case of French Idioms and Collocations Translated by Italian-speaking Adult Learners
}

\author{
Mariangela Albano ${ }^{1[0000-0001-7157-1482]}$ and Rosa Leandra Badalamenti ${ }^{2}$ \\ ${ }^{1}$ Dokuz Eylül University \& University Sorbonne Nouvelle, Paris \\ albanomariangela@gmail.com \\ ${ }^{2}$ University of Palermo \\ rosaleandra.bk@gmail.com
}

\begin{abstract}
This paper focuses on the treatment of French idioms and collocations by Italian-speaking adult learners of French as a foreign language. Since allophones do not have access to the figurative dimension that characterizes the frozen expressions of a language, mastery of them is very difficult and is usually only reached at an advanced stage of acquisition. The purpose of our study is to provide a contribution to the analysis of the semantic processing that takes place at the cognitive level in their interpretation. These processes will be approached from two perspectives of analysis: one pertaining to the acquisitional linguistics, aiming to examine the approaches and interpretative strategies put in place by foreign learners when confronted with an idiomatic expression, and the other pertaining to cognitive linguistics and aimed at the analysis of cognitive operations that create semantic networks of a metaphorical, metonymic and analogical nature.
\end{abstract}

Keywords: Idiom, Collocation, Acquisition of foreign languages, Analogy, Metaphor, Metonymy

\section{$1 \quad$ Introduction}

In this study, we analyze the interpretation strategies of 15 frozen expressions (henceforth FE) ${ }^{1}$ by advanced Italian-speaking learners of French as a foreign language (henceforth FFL). To analyze the processes of foreign language appropriation, different interdependent elements must be taken into account, such as the socio-cultural context in which the appropriation takes place, the learner's previous knowledge, his

1 The analyzed FE are: 1) poser un lapin, 2) se regarder le nombril, 3) yeux de biche, 4) tomber dans les pommes, 5) avoir la grosse tête, 6) filer à l'anglaise, 7) être un ours mal léché, 8) mettre de l'eau dans son vin, 9) mettre son grain de sel, 10) se mettre sur son trente et un, 11) casser sa pipe, 12) peigner la girafe, 13) parler politique ; 14) temps de cochon, 15) avoir du blé. 
level of metalinguistic awareness, or cognitive skills, developed during the learning path.

As far as FEs are concerned, the learner faces a double semantic opacity: the first is inherent to the approach of a foreign language (hence FL), since the learner has to deal with words structures and expressions that are unknown to him/her; the second is that FE requires the ability to make a transition between a literal level and a figurative level.

The attitude of the learner, his level of tolerance of linguistic ambiguity, his ability to fill the gaps are essential factors in the treatment of IE, treatment that we analyze here. The task of the learners was to interpret and translate texts that contained one or more word-for-word non-translatable FE into Italian.

Our approach is situated between cognitive linguistics and acquisitional linguistics: on the one hand, the cognitive approach can be useful for analyzing the cognitive projections activated during the processes of comprehension, translation and motivation of FE; on the other hand, the acquisition approach leads us to understand the processes of identification and isolation and, thanks to the analysis of the linguistic input processing operations implemented by the learners, can lead to possible didactic applications in the teaching of FEs in the FFL class².

\subsection{Lexicalization, Projection, and Analogy}

The study of lexicalization leads us to take into consideration a set of expressions in which morphosyntactic and lexical variations are limited. The FEs represents a unit that reveals a memory and psychological constant still perceived by the speakers of a language (Cacciari, 2001). If we base ourselves on the studies that concern the FEs, we can define the level of lexicalization based on seven criteria: polylexicality (G. Gross, 1996); non-compositionality (Wray, 2002); grammatical or syntactic block (Hudson, 1998; Gross, 1996), semantic block (Ibid.: 154), conventionality for which the set of words gives perception of unity (Nunberg et al., 1994: 493), block of synonymic paradigms (Shapira, 1999: 8-9; Gross, 1996) and semantic opacity (Gross, 1996).

In this study we have chosen to propose to the learners idioms (i.e. se regarder le nombril), and this for their high level of figurativity (Hudson, 1998; Moon, 1998: 1925; Norrick, 1985: 72; Brinton and Traugott, 2005; Svensson, 2004), some collocations (Burger, 2007; Benson, 1985), and some collocations in which only a segment possesses the linguistic status of idiom (i.e. yeux DE BICHE; être un OURS MAL LÉCHÉ).

The criteria for ranking FEs are not the only area on which phraseology studies have been concentrated: there has been increasing interest in, for example, cognitive

2 Mariangela Albano wrote: 1.Introduction, 1.1Lexicalization, projection and analogy, 2.3Activation of conceptual connections: metaphor, metonymy and analogy, 3.Conclusions; Rosa Leandra Badalamenti wrote: 1.2 FE in the acquisition of foreign languages, 1.3Methodology, 2.Analysis of data, 2.1Reference to context, 2.2. Analogies with L1 or other known languages, 3.Conclusions. 
analyzes. In this sense, the semantics of idioms aims to search for the motivation of IEs, to study the function of mental images in the use of these, or to explore the cultural phenomena that motivate them (Burger, 2007: 790; Dobrovol'skij and Piirainen, 2005).

To understand the cognitive aspects of IEs, the semantics of idioms use the theory of conceptual metaphor (Lakoff and Johnson, 1980) to analyze the cognitive processes underlying IE treatment. With regard to the metaphorical projection, the cognitive process takes place between a source domain and a target domain; as far as the metonymic projection is concerned, the process takes place within the same conceptual domain. In this study, we approach cognitive projection to seek to understand the translation and interpretation processes of learner-initiated IEs. It is also necessary to analyze the data from the analogy, a cognitive tool that allows learners to «group together in the same class or category» perceived «entities, consciously or not, as similar» (Monneret, 2003).

\subsection{FEs in the Acquisition of Foreign Languages}

According to Hudson, phraseology responds to principles of economy. Speakers repeat the expressions they have already heard instead of creating new ones each time. Indeed, since these are stored as a single lexical unit, they require much less processing effort at the time of production and their use increases the speed of speech and reduces the frequency of breaks.

However, a good knowledge of the FE would, according to Wood (2006) and Pawley \& Syder (2000: 195), the verbal fluidity «it is the store of memorized constructions and expressions, more than anything, that is the key to nativelike fluency». In addition, it seems that the use of FEs would allow non-native speakers (henceforth NNS) to express themselves in a more idiomatic and therefore more natural way «formulaic sequences used by native speakers are not easy for learners to identify and master, and [...] their absence greatly contributes to learners not sounding idiomatic» (Wray, 2002: 176).

Figurative language is rooted in everyday life and makes use of important factors in the process of appropriation of a FL, such as imagination and affectivity, and thus makes it possible to develop language expressivity (Ruiz Quemoun, 2007). In particular, idioms reflect the culture shared by a linguistic community and are therefore fundamental to getting closer to the culture of the target language.

In the acquisition of L1, the appropriation processes generally start from a holistic approach and go towards an analytical approach. In adult learners of a FL or L2, the opposite is true: the adult learner starts from an analytical approach, gradually evolving towards memory storage and holistic treatment of FE (Wray, 2002).

This has already been noted by Gibbs (1986), who emphasizes that native speakers (henceforth NS) do not activate the literal meaning of FEs unless the figurative meaning is irrelevant. On the contrary, NNSs try to activate a figurative meaning only when the literal meaning is perceived as irrelevant.

In the case of FL learning, another important factor that comes into play is the learning context. This is fundamental in that it determines the amount and type of 
input to which learners are subjected, as well as the types of interactions in which they participate. In the classroom, learners tend to adopt analytical approaches, especially if they have been subjected to a metalinguistic teaching of the grammar of the FL.

As we have seen, FEs have an ontological and cultural motivation. For foreign learners, the cultural sphere is not directly accessible. From this perspective, learning for a FL must also be distinguished from second-language learning, since in the second case learners have more opportunities to contact the target language. In FL learning, idioms can only be learned in the classroom, and the role of teachers and methods adopted becomes paramount. FEs are therefore an essential component of communication, acquisition and idiomaticity in FL. This is why it is useful to question the factors that may favor, or on the contrary, disadvantage, the development of learners.

\subsection{Methodology}

For our study, we chose 10 advanced learners of FFL in a university context. Students of our study have all studied French for at least 8 years, and they all have a master's degree in foreign languages. They have all been exposed to formal teachings of French grammar, and therefore tend to adopt analytical approaches to texts. We selected 15 FEs from dictionaries and data in short texts of different kinds (magazine extracts, daily newspapers, online forum, novels, and so on). We selected FEs which are not directly translatable into Italian. We asked the learners to translate or interpret the texts orally. Oral productions have been recorded and transcribed.

First, we focused on the isolation processes of FE within the text. We observed that, in most cases, learners were able to identify them even when they had never met them before. Subsequently, we asked about strategies and approaches taken by students to interpret FEs in a consistent way. We also considered the possible use of L1 in the treatment of FEs. In some cases, learners used their mother tongue or other known languages to try to interpret figurative expressions, but we also observed that, in most cases, they were able to avoid interference, demonstrating a high level of awareness of the cultural motivation of the chosen FEs. In this perspective, we questioned the processes of metaphorical or metonymic interpretation, in which learners abandoned their cultural sphere to engage in an ontological sphere, trying to reactivate symbolic processes from the literal meaning of the components of the FE.

\section{Data Analysis}

Interpretative approaches are based on an analytical approach that allows students to isolate FE within the text. Given the semantic opacity of the lexical unit, in most cases the isolation is based on processes of semantic relevance: in the given context, the lexical unit could not keep its literal and compositional meaning that was not relevant. Depending on the degree of accessibility of the context and the relevance of the FE speakers have put together or combined different interpretative strategies. If the con- 
text provides different or contradictory interpretative possibilities, the foreign speaker also uses other interpretative approaches, such as analogies with L1 and /or other known languages or even metonymic, analogical and metaphorical processes.

\subsection{Context Reference}

In our study, FEs were proposed within texts of different typologies. By context, we try to show the representations activated by the readers during the reading of the text.

NSs confronted with a figurative use of language, as in the case of unconventional metonymies, activate more interpretative hypotheses based on principles of relevance (Sperber and Wilson, 1986).

In one of the proposed texts, learners were asked to interpret the idiom poser un lapin, engl. stand somebody up, which appeared in a comics. The degree of semantic opacity and irrelevance to the context proved very high, and in most cases, after questioning the possible metaphorical values to be given to the expression, the students ended up with interpret from the image.

In another example, with the idiom se regarder le nombril, engl. to look on own navel, we see that the reader first assesses relevance with the context, before proceeding to a metaphorical interpretation of the FE.

\subsection{Analogies with L1 or Other Known Languages}

For foreign learners, L1 represents an inevitable interpretative tool. In the context of our study, we will not consider interference as an unconscious transfer of features from one language to another, but we will focus on the use of known languages as a conscious strategy in interpretation of the text.

In collocation n. 3 yeux de biche, the interpretation based on analogies with L1 is superior to contextual information and we could see two interpretative phases based on analogies with Italian.

At first, the learner selects the referent from a phonetic analogy between the French word biche [bif] and the Italian word biscia [bifa]. Subsequently, the interpretative choice is semantically motivated by metaphorical processes aiming at analogically transferring the characteristics of the animal biscia (engl.: grass snake) to the character of the comics, thus giving fr. yeux de salope, engl. slut eyes. However, the selected referent being irrelevant to the context, the learner subsequently uses another analogy with the L1 and in particular between the French collocation yeux de biche, engl. dee eyes, it. occhi da cerbiatta having the same meaning. We thus observe the transfer from a phonetic analogy to a semantic analogy allowing to advance an interpretative hypothesis more relevant to the context.

L1 has a prominent role in the interpretation of IEs, but learners do not just tap into it. In example n. 4 tomber dans les pommes, a student uses the Sicilian dialect. In particular, this student uses a Sicilian expression that has a certain degree of formal similarity with the French IE: tomber dans les pommes, engl. to fall in the apples and cariri comu a piru, engl. to fall like a peer share the same verbal base (tomber and

cariri) and in both expressions the argument of the verb is a fruit, hence the use of the 
Sicilian expression which is however deceptive compared to the signified of the French IE. In this example, we see how the reader does not limit himself to drawing on his prior knowledge, but also tries to give, through analogical methods, a semantic motivation to his interpretative choice.

\subsection{Activation of Conceptual Connections: Metaphor, Metonymy and Analogy}

It should be emphasized here that during the process of interpretation of idioms and collocations, students reactivate the semantics of these expressions through cognitive operations. The expression ne pas avoir la grosse tete, engl. not having the big head is interpreted correctly in the majority of the analyzed cases. However, some of the students translate the expression as being stupid. In fact, the inferences made by the learners show a stereotypical cultural evaluation according to which the footballers are stupid.

This evaluation is due, first, to a metonymy since the head is not simply a part of the body but represents the center of intelligence according to the report containercontent. Then, they subconsciously resort to conceptual metaphors more is up, the head is a container and the greater the amount of an entity increases in a container and the more positively the container is marked (Lakoff and Johnson, 1980), and they say that the bigger the head, the more intelligent the person involved is.

An interesting case is represented by the interpretation of FE se regarder le nombril, engl. looking at our own navel. First, the students translate IE with stare with the mani in mano (lit.: stay with hands in hand, and do nothing) using an analogy with a FE in L1. Then they come closer to an interpretative hypothesis of a metaphorical nature explaining the motivation of the FE through an embodied perspective. Indeed, students imagine the position of a person who is looking at the navel and they highlight the effects that such a position may have on the actions of the subject, such as the impossibility of moving, the obligation to remain bent over oneself to look at the navel, the obligation to remain extended and maintain a horizontal position. They find, therefore, that such a position prevents movement and forces us to do nothing.

The interpretation of the FE mettre son grain de sel (engl. put his grain of salt) is translated by some learners by metterci del suo (fig. give his/her opinion). Learners come to this translation by reflecting on the effects of salt in an injury and claim that salt burns. This allows them to reach, by analogical methods, the Italian expression mettere fuoco (engl. set fire) and connect analogically the effects of salt and fire. Students focus, then, on the effects of fire in a fire and they project metaphorically the idea that every element that burst into a foreign situation creates an alteration and that, in the same way, each person who gives his opinion in a foreign situation creates an alteration. 


\section{Conclusion}

Examples taken into account allows us to observe the interpretation processes developed by students to analyze idioms and collocations. We have marked that the activation of conceptual connections in the processing of FE does not take place from a single cognitive tool, but that students tend to juxtapose cognitive operations of a metaphorical, metonymic and analogical nature with the use of cognitive tools, context and analogies with known languages.

In some cases, students have focused their attention on the specificity of the conceptual relationships between the source domain and the target domain of FE and they obtained new inferences, showing us how primary conceptual metaphors work and operate in the dynamics of imaginative nature. This study has thus shown that students get own motivation of an idiom or a collocation by a path where the hypotheses and the remarks made during the treatment help them to «deep the notion of image from itself» (Monneret, 2004: 105).

In Foreign Language learning, learners deal with a cultural and connotative lag when trying to interpret a FE. As in the natural contexts of communication, they are forced to interpret the FE to interpret the entire message.

In addition, texts present different levels of semantic opacity since the foreign learner is already confronted with an input whose degree of ambiguity is high.

In our examples, the semantic opacity of FEs is usually solved by the use of context. If the latter does not lead to coherent interpretations, learners try to use their language skills in L1 or other known languages or to reactivate conceptual, metaphorical or metonymic processes.

Learners are well aware that frozen units are culturally motivated. They try to activate all of their linguistic, cultural and historical knowledge of the target language in order to translate the FE, and in some cases they push their analyzes to an ontological level.

Kövecses and Szabo (1996) argue that the presence of underlying cognitive metaphors in the mind is not sufficient to activate the use of FEs in foreign learners. According to Marquez (2007: 28), it is necessary to show learners that a great deal of phraseological expression is metaphorically motivated.

Explanation of the underlying metaphorical projections would be useful for the acquisition of equivalences among the conceptual frames that activate the FE.

Our study confirms that the analysis and the explanation of the underlying metaphors can indeed prove to be an asset in the appropriation of idioms and collocations. The effort made to negotiate their meaning, in relation to the context but also to the units that compose them, seems to be able to facilitate their storage in memory and processing. 


\section{References}

1. Benson, M.: Collocations and idioms. In R. Ilson (Ed.), Dictionaries, Lexicography and Language Learning VIII (pp. 61-68). Oxford : Pergamon (1985).

2. Brinton, L. J. \& Traugott E. C.: Lexicalization and Language Change. Cambridge : CUP (2005).

3. Burger, H. (Ed.): Phraseologie. Ein internationales Handbuch der zeitgenössischen Forschung. Berlin : Walter de Gruyter (2007).

4. Cacciari, C.: Psicologia del linguaggio. Bologna : Il Mulino (2001).

5. Dobrovol'skij, D.: Idiome aus kognitiver Sicht. In K. Steyer (Ed.), Wortverbindungen - mehr oder weniger fest (pp. 117-143). Berlin : Walter de Gruyter (2004).

6. Dobrovol'skij, D. \& Piirainen, E.: Figurative language: Cross-cultural and crosslinguistic perspectives. Amsterdam : Elsevier (2005).

7. Fontenelle, Th.: What on earth are collocations?. English today: the international review of the English language, 10. 4 (40), $42-48$ (1994).

8. Gibbs, R. W. Jr.: Skating on thin ice: Literal meaning and understanding idioms in conversation. Discourse Processes, 7, 17-30 (1986).

9. González, R. (Ed.) : Les expressions figées en didactique des langues étrangères. Fernelmont : E.M.E. (2007).

10. Gross, G. : Les expressions figées en français; noms composés et autres locutions. Paris : Éditions Ophrys (1996).

11. Hudson, J.: Perspectives on fixedness: applied and theoretical. Lund : Lund University Press (1998).

12. Kleiber, G.: Les proverbes: des dénominations d'un type 'très très spécial'. Langue française, 123, 52-69 (1999).

13. Kövecses, Z. \& Szabó P. : Idioms: a view from cognitive linguistics. Applied Linguistics, 17, 326-355 (1996).

14. Lakoff, G. \& Johnson, M.: Metaphors we live by. Chicago : The University of Chicago Press (1980).

15. Martin, R. : Sur les facteurs du figement lexical. In M. Martins-Baltar (Ed.), La locution entre langue et usages (pp. 291-305). Fontenay Saint Cloud : ENS Éditions (1997).

16. Mel'čuk, I. : La phraséologie et son rôle dans l'enseignement/apprentissage d'une langue étrangère. Étude de Linguistique Appliquée, 92, 82-113 (1993).

17. Monneret, $\mathrm{Ph}$. : Le sens du signifiant. Implications linguistiques et cognitives de la motivation. Paris : Champion (2003).

18. Monneret, Ph. : Essais de linguistique analogique. Dijon : A.B.E.L.L. (2004).

19. Moon, R.: Fixed expressions and idioms in English, a corpus-based approach. Oxford : Clarendon Press (1998).

20. Norrick, N. R.: How proverbs mean: semantic studies in English proverbs. Berlin : Mouton (1985).

21. Nunberg, G.; Sag, I. A. \& Wasow, T. (Eds): Idioms. Language, 70, 3, 491-538. Washington DC: Linguistic Society of America (1994). 
22. Pawley, A. \& Syder, F. H.: The One-Clause-at-a-Time $\neg$ Hypothesis. In H. Riggenbach (Ed.), Perspectives on Fluency (pp. 163-199). University of Michigan Press (2000).

23. Schapira, Ch. : Les stéréotypes en français : proverbes et autres formules. Paris : Éditions Ophrys (1999).

24. Sperber, D. \& Wilson, D.: La pertinence: communication et cognition. Paris : Editions de Minuit (1986).

25. Svensson, M. H. : Critères de figement. L'identification des expressions figées en français contemporain. Umeå : Tommy Sund (2004).

26. Wood, D.: Uses and Functions of Formulaic Sequences in Second Language Speech: An Exploration of the Foundations of Fluency. The Canadian Modern Language Review, 63, 1, 13-33 (2006).

27. Wray, A.: Formulaic Language and the Lexicon. Cambrige : Cambridge University Press (2002).

\section{Dictionaries}

28. Imbs, P. (Ed.): Trésor de la langue française. Dictionnaire de la langue du XIX et du XX siècle (1789-1960). Tome troisième. Paris : Éditions du Centre National de la Recherche Scientifique (1974).

29. Imbs, P. (Ed.) : Trésor de la langue française. Dictionnaire de la langue du XIX et du XX siècle (1789-1960). Tome septième. Paris : Éditions du Centre National de la Recherche Scientifique (1979).

30. Gorcy, G. (Ed.) : Trésor de la langue française. Dictionnaire de la langue du XIX et du XX siècle (1789-1960). Tome seizième. Paris : Gallimard (1994).

31. Pottier, B. (Ed.) : Trésor de la langue française. Dictionnaire de la langue du XIX et du XX siècle (1789-1960). Tome dixième. Paris : Éditions du Centre National de la Recherche Scientifique (1983).

32. Pottier, B. (Ed.) : Trésor de la langue française. Dictionnaire de la langue du XIX et du XX siècle (1789-1960). Tome onzième. Paris : Gallimard (1985).

33. Robert, P. (Ed.) Le nouveau petit Robert de la langue française 2007: dictionnaire alphabétique et analogique de la langue française. Paris : Le Robert (2007).

Sitography

34. BiblioBabil: Mon Ipad a cassé sa pipe. http://bibliobabil.com/2011/05/16/monipad-a-casse-sa-pipe/, last accessed 2012/03/15 (2011).

35. Commune de Bellonne : L'ancêtre du G.P.S. à Bellonne. http://www.bellonne.fr/pageLibre000103d8.html, last accessed 2012/03/15 (2012).

36. Futura Forum : Que se passe-t-il quand on tombe dans les pommes ? http://forums.futura-sciences.com/sante-medecine-generale/156930-se-passe-t-ontombe-pommes.html, last accessed 2012/03/15 (2004). 
37. L'île de Crète : Voyage en images. Forum des voyageurs. Re : Athena Palace. http://www.ile-de-crete.com/forums/read.php?1,11681,12095, last accessed 2012/03/15 (2006).

38. Le Figaro.fr. : Abidal : «Au Barça, on ne se regarde pas le nombril». http://www.lefigaro.fr/sport/2011/03/07/02001-20110307ARTFIG00665-abidalau-barca-on-ne-se-regarde-pas-le-nombril.php, last accessed 2012/03/15 (2011).

39. Le Figaro.fr : Les républicains se cherchent un champion contre Obama. http://www.lefigaro.fr/international/2011/05/06/01003-20110506ARTFIG00615les-republicains-se-cherchent-un-champion-contre-obama.php, last accessed 2012/03/15 (2011).

40. Le Figaro.fr. : François Hollande en tête-à-tête avec la reine Elizabeth. http://www.lefigaro.fr/international/2012/07/10/01003-20120710ARTFIG00591hollande-a-discute-en-tete-a-tete-avec-la-reineelizabeth.php?page $=\&$ pagination=17, last accessed 2012/07/25 (2012).

41. Plurielles.fr. : Beauté homme : quels soins basiques pour ses premiers pas ? http://www.plurielles.fr/beaute/soins/beaute-homme-quels-soins-basiques-pourses-premiers-pas-7219330-402.html, last accessed 2012/06/15 (2012). 